\title{
PERANGKAT RETORIKA DALAM MAZMUR 145
}

oleh: Paulus Dimas Prabowo*

Email: paul110491@gmail.com

Sekolah Tinggi Teologi Injili Indonesia

\begin{abstract}
Interpretting a poetry isn't easy work. The writer uses many rhetorical devices to deliver the message to the reader. The message is clothed with beauty. People could find it in Psalms of Old Testament. What a magnificient work is it; the divine message's voiced through a beauty. Our eyes are too blur to see the beauty and the message, untill we find the rhetorical devices which used in. The main purpose of this article is showing the function of rhetorical devices to find the idea and message. Another purpose is to show how conversant the writer creates his poetry and how he uses the rhetorical devices skillfully. Through this article, we will see an example is demonstrated through Psalm 145.
\end{abstract}

Key Words: Genre, Structure, Inclusio, Acrostic, Repetitio, Figures, Theme

\section{Pendahuluan}

Lahirnya puisi sebagai sebuah retorika adalah hal yang layak disyukuri. Sebab sejak awal mula kemunculannya kurang lebih pada milenium ketiga sebelum Masehi, lewat karya berjudul Epic of Gilgamesh ${ }^{1}$, puisi terus-menerus dipakai orangorang dari zaman ke zaman untuk menyampaikan pesan. Termasuk di dalamnya ialah para penulis kitab Perjanjian Lama. Pesan yang dikemas dalam keindahan dan sentuhan perasaan, kiranya mampu dipahami sekaligus dinikmati.

Kitab Mazmur merupakan salah satu kitab bergenre puisi ${ }^{2}$ dengan seratus lima puluh pasal yang masing-masing unik. Menemukan pesan sekaligus keindahan di dalamnya bukanlah perkara gampang bagi semua orang. Diperlukan kajian mendalam di setiap pasalnya melalui prosedur hermeneutik yang memadai. Intelektual seseorang didayagunakan sedemikian rupa untuk menggali dan menemukan kebenaran. Namun jika bicara soal kitab puisi, aspek emosional tak boleh diabaikan. Itu sebabnya puisi menyediakan perangkat-perangkat retorika (rhetorical devices) yang perlu dipelajari agar aspek intelektual dan emosional dalam sebuah mazmur mampu terpahami.

*Paulus Dimas Prabowo, M.Th adalah seorang dosen yang mengajar di Sekolah Tinggi Teologi Injili Indonesia - Yogyakarta.

${ }^{1}$ Epic of Gilgamesh adalah syair kepahlawanan dari Akkadia yang menceritakan usaha seorang raja dalam menghindari kematian. Karya ini dianggap sebagai puisi tertua dan terus dikenal di kemudian hari pada periode Persia dan Romawi. Benjamin R. Foster, "Literature and Poetry, Ancient Near East" dalam The Encyclopedia of Ancient History, peny. Roger S. Bagnall dkk, 1st edition (Hoboken, New Jersery: Blackwell Publiher, 2013), 4108-4110.

2 Tremper Longman III, Bagaimana Menganalisa Kitab Mazmur, pen. Cornelius Kuswanto (Malang: Literatur SAAT, 2012), 104. 
Karya tulis ini akan membahas perangkat retorika apa saja yang terkandung dalam Mazmur 145. Pasal ini dipilih karena memiliki perangkat retorika yang cukup bervariasi. Tujuannya ialah membuktikan bahwa pesan yang utuh dalam sebuah mazmur hanya bisa ditemukan dengan mempelajari perangkat retorika yang dipakai pemazmur. Selain itu, artikel ini juga bertujuan untuk menunjukkan kepiawaian penulis mazmur dalam meramu puisinya dengan variasi perangkat retorika, sehingga aspek estetikanya dapat nampak dan dilihat oleh pembaca.

\section{Signifikansi Perangkat Retorika}

Retorika merupakan sebuah ketrampilan berbahasa. ${ }^{3}$ Tujuannya adalah strategi persuasif, yakni mempengaruhi pembaca untuk sepakat dengan gagasan yang disampaikan. Guna mencapai tujuan tersebut digunakanlah perangkat retorika. Perangkat retorika sendiri dapat diartikan sebagai sarana kepuitisan sebagai tipu muslihat pikiran pengarang dengan menggunakan konstruksi bahasa yang sedemikian rupa sehingga pembaca atau pendengar dituntut untuk berpikir. ${ }^{4}$ Singkatnya, perangkat retorika merupakan sarana yang mengupayakan tercapainya tujuan retorika. Secara garis besar, perangkat retorika mencakup tiga hal, yakni pemajasan, strukturisasi sastra, dan pelukisan (imagery). ${ }^{5}$ Ada yang mengelompokkan pemajasan dan pelukisan sebagai kiasan. Kiasan merupakan tekstur puisi Ibrani. ${ }^{6}$ Maka, bisa dikatakan bahwa perangkat retorika terdiri atas struktur dan tekstur puisi.

Keberadaan perangkat retorika dalam sebuah puisi bukan tanpa kepentingan. Seorang penyair memformulasi ragam perangkat retorika dalam tulisannya guna menimbulkan ketegangan puitis, karena pembaca dirangsang untuk memikirkan efek yang dimaksud sang penyair. ${ }^{7}$ Sehingga melaluinya, emosi dan imajinasi para pembaca dimainkan sedemikian rupa. Stek menambahkan,bahwa perangkat retorika juga berfungsi memusatkan perhatian pada tema utama dan menyusun keseluruhan puisi menjadi sebuah kesatuan artistik dan juga tematik. ${ }^{8}$ Dengan demikian, dapat dipahami sekarang, bahwa kepentingan dari perangkat retorika yang terformulasi di dalam puisi adalah memberi efek emosional bagi pembaca dan membantu pembaca untuk menemukan tema dan kesatuan di dalamnya.

${ }^{3}$ Dendy Sugono, Kamus Bahasa Indonesia (Jakarta: Pusat Bahasa, 2008), 1205.

${ }^{4}$ Rachmat Djoko Pradopo, Pengkajian Puisi (Yogyakarta: Gadjah Mada university Press, 2000), 93.

${ }^{5}$ Burhan Nurgiyantoro, Teori Pengkajian Fiksi (Yogyakarta: Gadjah Mada University Press, 1995), 295-296.

${ }^{6}$ Carl A. Reed, Diktat Kuliah: "Puisi dalam Kitab PL” (Yogyakarta: STTII, t.t), 8.

${ }^{7}$ Andri Wicaksono, Pradopo dalam Catatan Ringkas Stilistika (Yogyakarta: Garudhawaca, 2014), 29.

${ }^{8}$ John H. Stek, "The Stylistics of Hebrew Poetry," Calvin Theological Journal 9.1: 15-30 (Grand Rapids, Michigan: Calvin Theological Seminary, 1974), 18. 


\section{Introduksi Mazmur 145}

Mazmur 145 termasuk dalam Buku Mazmur jilid V. ${ }^{9}$ Kemungkinan besar mazmur-mazmur dalam jilid tersebut, termasuk Mazmur 145, terkompilasi pada zaman Ezra (pasca pembuangan). ${ }^{10}$ Waltner menuturkan, banyaknya penafsir menyatakan demikian berdasarkan pertimbangan struktur mazmur, keterkaitan dengan mazmur lain, kosakata Ibrani yang lebih belakangan, dan juga konsep Yahweh sebagai Raja. ${ }^{11}$ Meskipun diredaksi pada era pasca pembuangan sekitar tahun 536-425

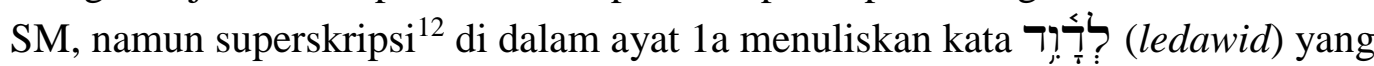
memberikan petunjuk bahwa Daud adalah penulisnya.

Superskirpsi tersebut juga memberi petunjuk tentang genre Mazmur 145. Harus dimengerti bahwa superskripsi dalam sebuah mazmur tidak hanya memberi informasi tentang pengarang mazmur dan petunjuk teknis dalam menyanyikannya. Whybray mengatakan bahwa superskripsi dapat mengindikasikan genre mazmur. ${ }^{13}$

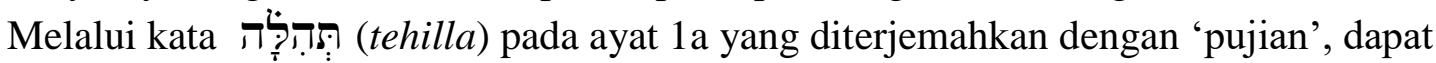
dilihat bahwa genrenya adalah Mazmur Pujian atau Psalm of Descriptive Praise. Sebutannya yang lain adalah Mazmur Himnik. Mazmur bergenre ini pada umumnya berisikan kata-kata pujian kepada TUHAN atas karya-Nya; secara umum berkaitan dengan karya penciptaan atas semesta dan secara khusus berkaitan dengan karya pembebasan atas umat-Nya. Selain dari superskripsi, genre Mazmur 145 juga dapat dikenali lewat mood di dalamnya, dimana pemazmur memenuhi mazmurnya dengan kata-kata pujian bernada sukacita. Mazmur ini merupakan himne yang dinyanyikan di Bait Suci pada hari-hari suci, baik oleh paduan suara Bait Suci maupun oleh umat. ${ }^{14}$

Salah satu keunikan Mazmur 145 ialah perannya sebagai jembatan dari baris-baris ratapan menuju rangkaian puji-pujian. ${ }^{15}$ Enam mazmur sebelumnya, yakni Mazmur 139-144, sarat akan ratap keluh kesah dan permohonan minta tolong.

Sedangkan lima mazmur sesudahnya, yakni Mazmur 146-150, berisi puji-pujian yang diawali dan diakhiri dengan kata "haleluya."

${ }^{9}$ Kitab Mazmur dibagi ke dalam lima jilid buku, meliputi: Jilid I (Mazmur 1-41), Jilid 11 (Mazmur 42-72), Jilid III (Mazmur 73-89), Jilid IV (Mazmur 90-106), dan Jilid V (Mazmur 107-150). C. Hassel Bullock, Kitab-kitab Puisi dalam Perjanjian Lama, peny. Sumarah, pen. Suhadi Yeremia (Malang: Gandum Mas, 2014), 158.

${ }^{10}$ Michael D. Goulder, The Psalms of the Return: Book V, Psalm 107-150, peny. David J.A. Clines dan Philip R. Davies (Sheffield: Sheffield Academic Press, 1998), 212.

11 James H. Waltner, Believers Church Bible Commentary: Psalm, pen. Elmer A. Martens dan Willard M. Swartley (Pennsylvania: Herald Press, 2006), 691.

${ }^{12}$ Superskripsi adalah teks informatif yang mendahului tubuh utama lagu.

${ }^{13}$ Norman Whybray, "Reading The Psalms As A Book," Journal for the Study of the Old Testament (Sheffield: Sheffield Academic Press, 1996): 20.

${ }^{14}$ C. Hassel Bullock, Kitab-kitab Puisi dalam Perjanjian Lama, 184.

15 James H. Waltner, Believers Church Bible Commentary: Psalm, 690. 


\section{Investigasi Perangkat Retorika dalam Mazmur 145}

Memang secara garis besar ada tiga bentuk perangkat retorika, yakni pemajasan, strukturisasi sastra, dan pelukisan. Tetapi tiap-tiap bentuk masih memiliki variannya masing-masing yang begitu banyak. Majas memiliki banyak jenis, seperti ironi, hiperbola, eufimisme, alusi, satir, paradoks, dan yang lainnya. Terkait dengan strukur, dikenal yang namanya paralelisme, inklusio, anafora, repetisi, akrostik dan lain-lain. Lalu ketika bicara soal pelukisan, maka akan muncul istilah-istilah seperti metafora, simile, personifikasi, antropomorfisme, alegori, dan sebagainya. Tidak semuanya termuat dalam Mazmur 145. Hanya beberapa saja akan dijelaskan dalam artikel ini.

\section{Inklusio}

Dengan mengutip pernyataan Dahood, Grossberg mendefinisikan inklusio sebagai "perangkat retoris yang juga disebut komposisi siklikal, di mana penulis kembali ke titik dimana ia mulai." "Longman menegaskannya dengan mengatakan bahwa inklusio adalah "pengulangan yang membuka dan menutup sebuah syair." 17 Sebutan lain untuk perangkat retorika ini adalah ringcomposition, bracket figure, atau envelope figure. Inklusio terletak di awal dan akhir sebuah mazmur dengan kata-kata yang persis sama atau serupa.

Secara umum, inklusio dipahami fungsinya sebagai penyedia kohesi dan kesatuan sebuah puisi. ${ }^{18}$ Namun perlu digarisbawahi, inklusio juga dapat menjadi petunjuk tema sebuah mazmur. Bartholomew menjelaskan bahwa "inklusio adalah sejenis pengulangan yang membatasi suatu bagian dan mengindikasikan tema utama dari bagian tersebut." "19 Senada dengan pendapat ini, Carley pun mengatakan: "Inklusio menyajikan sebuah tema yang penting dari mazmur ... ." Kiranya jelas, bahwa tema sebuah mazmur dapat ditentukan lewat inklusionya.

Inklusio dalam Mazmur 145 ditemukan di dalam ayat 1-2 dan ayat 21. Ayat 1b berbunyi: “Aku hendak mengagungkan Engkau, ya Allahku, ya Raja, dan aku hendak memuji nama-Mu untuk seterusnya dan selamanya." Dan ayat 2 melanjutkan: "Setiap hari aku hendak memuji Engkau, dan hendak memuliakan nama-Mu untuk seterusnya dan selamanya." Klausa terakhir pada masing-masing ayat adalah serupa.

97.

${ }^{16}$ Daniel Grossberg, “The Disparate Elements Of The Inclusio In Psalms,” HAR 6 (1982),

${ }^{17}$ Tremper Longman III, Bagaimana Menganalisa Kitab Mazmur, 129.

${ }^{18}$ Michale K. Snearly, The Return of The King: Messianic Expectation in Book V of the Psalter (New York: Bloomsbury Publishing, 2016) ,110.

${ }^{19}$ Craig G. Bartholomew, Reading Proverbs with Integrity (Cambridge: Grove Books, 2001), 8 .

${ }^{20}$ Keith Carley, "Psalm 8: An Apology for Domination" Reading from the Perspective of Earth, peny. Norman C. Habel, (Sheffield: Sheffield Academic Press, 2000), 115. 


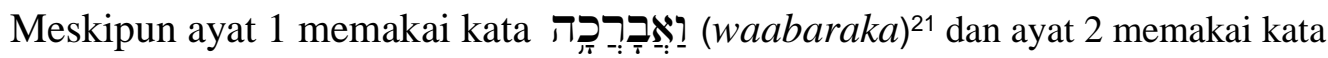

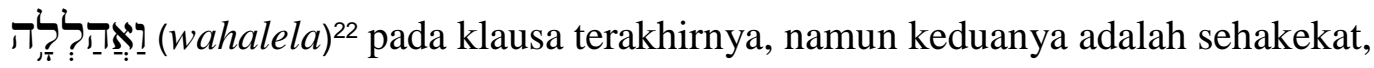
yakni menekankan pujian kepada TUHAN. Keduanya juga merupakan kata kerja dengan bentuk piel yang menekankan intensivitas atau tindakan berulang-ulang. ${ }^{23}$

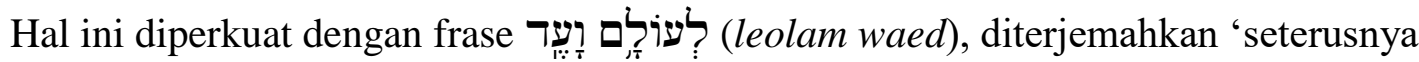
dan selamanya,' yang muncul pada akhir setiap ayat. Maka, gagasan yang ditonjolkan pada bagian awal mazmur ini adalah 'memuji TUHAN seterusnya dan selamanya.'

Bagian akhir dari Mazmur 145, ayat 21, menunjukkan pola yang serupa.

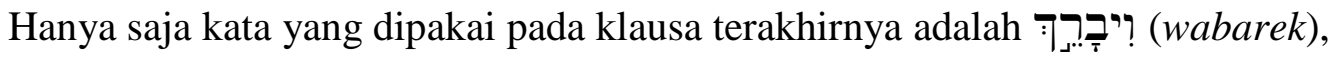

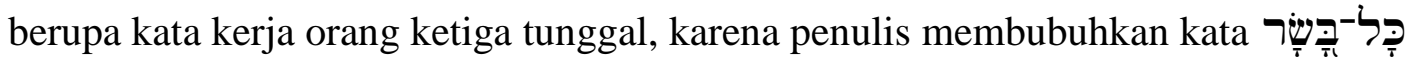
(kal-basar) sebagai subjek pemuji. Alkitab LAI menerjemahkannya dengan frase 'segala makhluk'. Secara harafiah kal-basar berarti 'segala daging' namun terjemahan yang lebih tepat pada ayat tersebut adalah 'segala umat. ${ }^{24}$ Dan harus diakui bahwa pemazmur menggunakan sebutan berbeda untuk objek yang sama pada bagian pembuka dan penutup. Pada bagian pembuka, ayat 1, pemazmur memakai frase

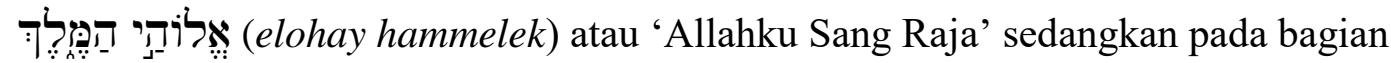
penutupnya pemazmur memakai יִ ירוֹ berarti mengenai hal ini. Goulder mengungkapkan bahwa pemazmur sedang menyapa TUHAN dengan sebutan "Allahku" yang kerajaan-Nya menjadi suatu realita nyata. ${ }^{25}$ Namun kembali lagi, ayat 21 sejajar dengan ayat 1-2, dimana pemazmur mengatakan: "Mulutku mengucapkan puji-pujian kepada TUHAN dan biarlah segala makhluk memuji nama-Nya yang kudus untuk seterusnya dan selamanya." Bagian penutup ini

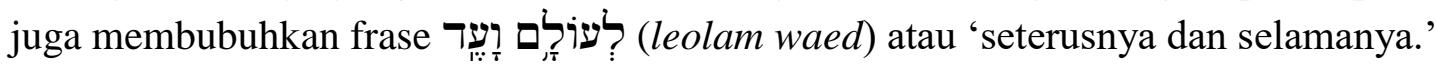
Inklusio dalam Mazmur 145 terdiri dari pembuka dan penutup yang gagasannya adalah 'memuji TUHAN seterusnya dan selamanya.' Pembandingan di bawah ini kiranya semakin memperjelas:

${ }^{21}$ Kata dasarnya adalah בּרך] (barak) yang secara umum diartikan "memberkati," namun dalam konteks Mazmur 145:1 ini arti yang paling masuk akal adalah "memuja dengan lutut bertelut." Francis Brown, S.R. Driver, Charles A. Briggs, The Brown-Driver-Briggs Hebrew and English Lexicon (Oxford: Clarendon Press, 1907), 138.

${ }^{22}$ Berasal dari kata הלל (halal) yang artinya "memuji" dan bersinonim dengan barak; pada dasarnya kata halal menjelaskan sebuah ketulusan dan kesungguhan dalam memuji sesuatu atau seseorang yang superior dan perbuatan akbar-Nya. Sedangkan pemakaiannya dalam Mazmur 145:2 menekankan "orang saleh yang mendeklarasikan niatnya untuk memuji TUHAN.” Leonard J. Coppes, Theological Wordbook of the Old Testament (500), peny. R. Laird Harris (Chicago: Moody Press, 1981) dalam Bibleworks 9.

${ }^{23}$ A.E. Cowley, Gesenius Hebrew Grammar (New York: Oxford University Press, 1910), 141.

${ }^{24}$ Francis Brown, S.R. Driver, Charles A. Briggs, The Brown-Driver-Briggs Hebrew and English Lexicon, 141.

${ }^{25}$ Michael Goulder, "The Psalm of the Return (Book V, 107-150)," Journal for the Study of the Old Testament (1997): 281. 
Aku hendak mengagungkan Engkau, ya Allahku, ya Raja,

dan aku hendak memuji nama-Mu untuk seterusnya dan selamanya. (ay. 1)

Mulutku mengucapkan puji-pujian kepada TUHAN,

dan biarlah segala makhluk memuji nama-Nya yang kudus untuk seterusnya dan selamanya. (ay. 21)

Dapat dilihat, masing-masing ayat berpola bikola (dua baris), dan kola terakhir pada tiap ayat adalah sejajar. Keduanya memberi gagasan 'memuji nama TUHAN seterusnya dan selamanya.' Klausa yang serupa ini membentuk inklusio sekaligus mengindikasikan tema Mazmur 145. Penulis mengusulkan tema mazmur ini ialah 'Memuji TUHAN Seterusnya dan Selamanya.' Namun perlu juga untuk melihat bukti lebih banyak dari perangkat retorika lain dan isi mazmur sendiri untuk mengukuhkan usulan ini.

\section{Akrostik}

Dunia sastra Timur Dekat kuno pada umumnya mengenal dan memakai pola akrostik sebagai salah satu perangkat retorika dalam literatur sastra mereka. Selain Akrostik Ibrani, beberapa yang telah ditemukan di antaranya adalah Akrostik Ugarit, Akrostik Akkadia, dan Akrostik Mesir. ${ }^{26}$ Akrostik adalah sebuah puisi yang huruf pertama dari setiap barisnya membentuk sebuah pola tersendiri. ${ }^{27}$ Pola ini biasanya dipakai untuk mengawali baris, bikolon, trikolon, bahkan stanza/bait. ${ }^{28}$ Variasi pemakaian tersebut dapat dijumpai dalam Kitab Mazmur. Mazmur 111 dan 112 memakai akrostik untuk mengawali setiap barisnya (satu kola, setengah ayat). Mazmur 24, 34, dan 145 memakai akrostik untuk mengawali bikola (satu ayat). Pemakaian akrostik untuk mengawali tetrad (empat baris, dua ayat) dapat dijumpai dalam Mazmur 9-10. ${ }^{29}$ Sedangkan contoh pemakaian akrostik untuk mengawali stanza (delapan ayat) dapat terlihat dalam Mazmur 119. Jenis akrostik yang dipakai dalam kitab-kitab Perjanjian Lama adalah akrostik alfabetik. ${ }^{30}$

${ }^{26}$ Dalam artikelnya, Brugg mengomparasikan puisi akrostik Ibrani dalam Alkitab dengan puisi-puisi akrostik Timur Dekat Kuno dalam harapan menemukan tujuan, orisinalitas, dan hubungan dengan akrostik bangsa sekeliling Isarel. John F. Brugg "Biblical Acrostics And Their Relationship To Other Ancient Near Eastern Acrostic," NEH Seminar: The Bible And Near Eastern Literature (1997): 4-6.

${ }^{27}$ Tremper Longman III, Bagaimana Menganalisa Kitab Mazmur, 129.

${ }^{28}$ John F. Brugg, "Biblical Acrostics And Their Relationship To Other Ancient Near Eastern Acrostic," 1.

${ }^{29}$ Teks Septuaginta menggabungkan Mazmur 9-10 sebagai 1 mazmur.

${ }^{30}$ Ada beberapa jenis akrostik yang dikenal, yakni Telestik, Mesostik, Akrostik Ganda, dan Akrostik Alfabetik (biasa disebut Akrostik Abecedarian). Kitab-kitab Perjanjian Lama, termasuk Kitab Mazmur, memakai jenis akrostik yang keempat, yakni Akrostik Alfabetik. Roelie van der Spuy, "Hebrew Alphabetic Acrostic - Significance and Translate," OTE 21/2 (2008): 513. 
Di bawah ini merupakan teks Ibrani dari Mazmur 145 untuk dapat melihat urutan abjad Ibrani pada masing-masing ayat (bikola). Superskripsi tidak disertakan.

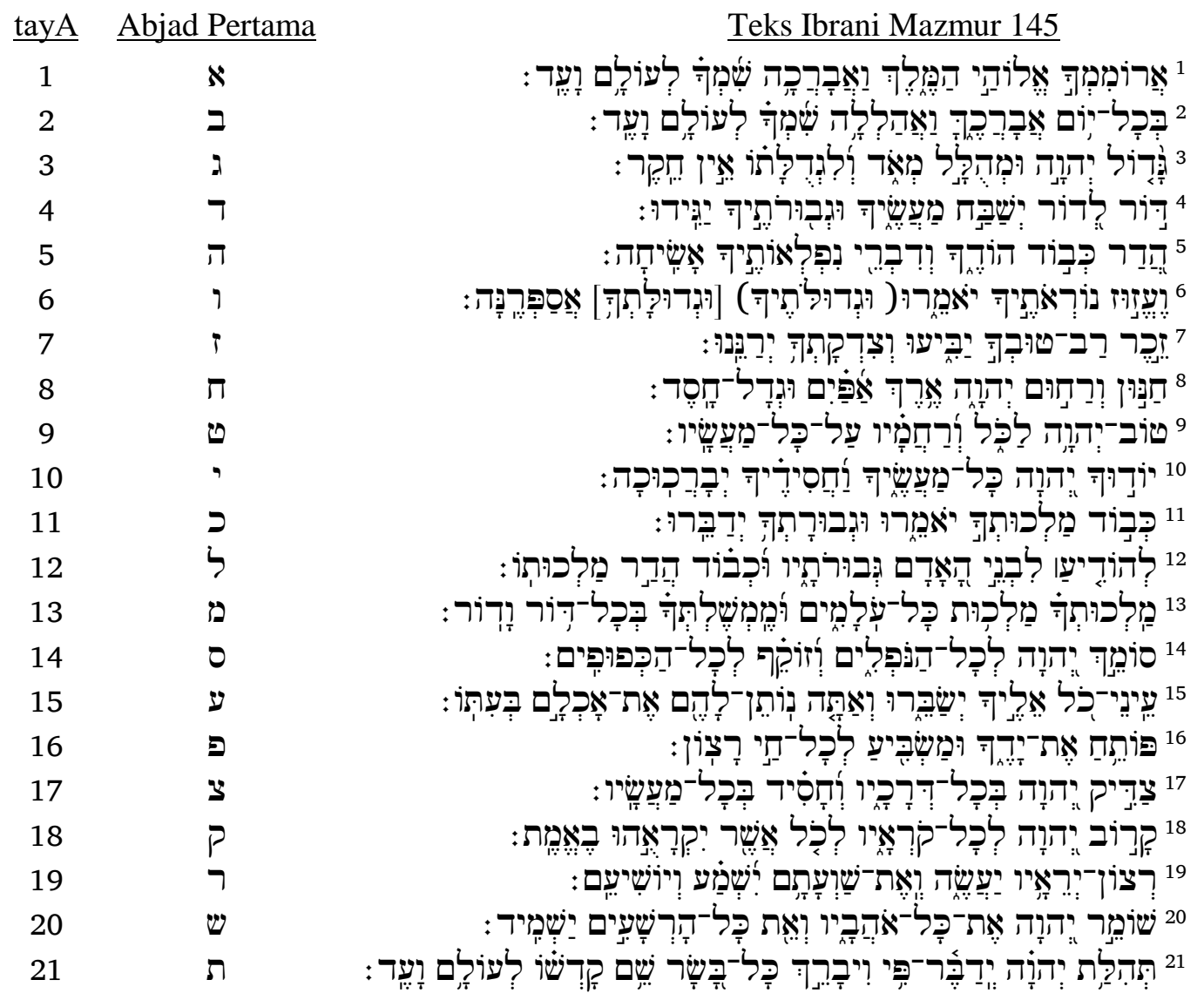

Dapat dilihat bahwa masing-masing ayat mewakili satu abjad Ibrani secara berurutan. Hanya saja abjad I (nun) tidak ada di dalam mazmur tersebut. Diskusi mengenai hilangnya abjad tersebut akan panjang, namun tidak akan dibahas dalam artikel ini.

Yang lebih perlu didiskusikan ialah: apa tujuan seseorang penulis memakai pola akrostik? Penulis mengajukan tiga tujuan dari pemakaian akrostik, yakni tujuan estetis, tujuan didaktis, dan tujuan tematis.

\section{Tujuan Estetis}

Longman mengungkapkan bahwa salah tujuan akrostik ialah tujuan estetika, yakni unsur keindahan seni untuk menyenangkan penyair-penyair Israel. ${ }^{31}$ Pola akrostik mampu merangsang aspek sensoris penikmat puisi, khususnya aspek visual dan aural (penglihatan dan pendengaran). ${ }^{32}$ Ketika seseorang membaca puisi akrostik atau mendengar pembacaannya, maka ia akan menjumpai keindahan rangkaian abjad secara berurutan. Pembaca atau pendengar diajak berpengalaman dengan inderanya. Hasilnya ialah kepuasan dan kekaguman akan sebuah karya seni.

\footnotetext{
${ }^{31}$ Tremper Longman III, Bagaimana Menganalisa Kitab Mazmur, 130.

${ }^{32}$ Roelie van der Spuy, "Hebrew Alphabetic Acrostic - Significance and Translate," 158.
} 


\section{Tujuan Didaktis}

Dengan mengutip pendapat Rabbi Yalkut Shimoni, Spruy menjelaskan bahwa tujuan pemakaian pola akrostik dalam puisi bukan sekedar soal keindahan belaka, namun juga ada tujuannya didaktisnya. ${ }^{33}$ Senada dengan Spruy, Brug berkata: "This didactic tone seems to be a common emphasis of biblical acrostics." 34 Jika tujuan estetis adalah tentang merangsang aspek emosional pembaca, maka tujuan didaktis adalah tentang merangsang intelektual seseorang. Longman menjelaskan bahwa akrostik bertujuan sebagai alat bantu yang memudahkan pembaca untuk mengingat. ${ }^{35}$ Istilah yang lain adalah 'mnemonik.' Jadi pikiran pembaca dirangsang agar mampu mengingat pelajaran yang disampaikan pemazmur melalui syairnya.

\section{Tujuan Tematis}

Melalui pola akrostik, pembaca dapat memahami keindahan rangkaian urutan abjad Ibrani yang mengawali ayat demi ayat dalam Mazmur 145. Pembaca dibuat terkagum akan kepiawaian pemazmur menyusun syairnya, namun lebih daripada itu, kagum kepada Allah yang memakai karya seni tingkat tinggi untuk menyampaikan sabda-Nya. Melalui pola akrostik pula, pembaca dirangsang pikirannya; setidaknya penerima mula-mula dalam komunitas Ibrani dimudahkan mengingat ayat demi ayat dan memahami pesannya.

Namun satu hal yang tak kalah penting ialah tujuan tematis dari pola akrostik. Telah disebutkan di awal, bahwa perangkat retorika yang dipakai dalam puisi adalah untuk menemukan tema dan kesatuan di dalamnya. Spruy menyatakan bahwa pola akrostik alfabetik yang meliputi abjad dari aleph sampai taw dalam Mazmur 145, menunjukkan sebuah kesatuan, kelengkapan, dan keseluruhan. ${ }^{36}$ Kemudian Spruy menambahkan: "Kerangka alfabetik tersebut mempertajam tema yang tak terceraikan dari puisi tersebut." 37 Jadi, bisa dikatakan bahwa pemakaian akrostik alfabetik adalah seni mengurung tema di dalam dinamika urutan abjad. Akrostik alfabetik menahan sesuatu tetap statis melalui bingkai yang dinamis.

Perlu dipahami bahwa bentuk puitis, isi dan pesan cukup sering terjalin. ${ }^{38}$ Bentuk akrostik dan isi pesan saling terintegrasi. Mazmur 145 mengajak seluruh umat untuk memuji TUHAN untuk seterusnya dan selamanya, dari awal sampai akhir hidup seseorang. Ayat demi ayat di dalamnya berisi kerinduan dan alasan-alasan untuk memuji TUHAN seterusnya dan selamanya.

${ }^{33}$ Roelie van der Spuy, "Hebrew Alphabetic Acrostic - Significance and Translate," 519.

${ }^{34}$ John F. Brugg, "Biblical Acrostics And Their Relationship To Other Ancient Near Eastern Acrostic," 4.

${ }^{35}$ Tremper Longman III, Bagaimana Menganalisa Kitab Mazmur, 130.

${ }^{36}$ Roelie van der Spuy, "Hebrew Alphabetic Acrostic - Significance and Translate," 517.

${ }^{37}$ Ibid.

${ }^{38}$ Ibid. 


\section{Repetisio}

Repetisio adalah pengulangan kata atau rangkaian kata yang sama secara tidak teratur dalam bagian yang sama. ${ }^{39}$ Disebut tidak teratur karena letaknya yang tidak dibatasi posisi; tidak harus di awal, di tengah, atau di akhir suatu bagian, bahkan tidak ada pola interval tertentu. ${ }^{40}$ Repetisio hanyalah satu dari sekian banyak jenis pengulangan. Bullinger dalam karyanya berjudul Figure of Speech Used In The Bible menyebutkan bermacam-macam jenis pengulangan dan banyak di antaranya yang terikat aturan. ${ }^{41}$ Pada hakekatnya, repetisio adalah pengulangan kata yang sama pada bagian-bagian tertentu. Fungsinya ialah memberi penekanan atau mengundang perhatian pembaca. ${ }^{42}$

Penggunaan repetisio terkait dengan penentuan unit-unit dalam garis besar sebuah mazmur. Unit atau satuan adalah komponen penting dalam menyusun outline sebuah mazmur. Tidak sedikit karya telah diterbitkan berkenaan dengan garis besar Mazmur 145 dan hampir selalu berbeda, tidak sama persis satu dengan yang lainnya. Hal ini wajar, karena setiap orang memiliki sudut pandangnya sendiri. Tambahan lagi, ada banyak cara dalam menentukan unit-unit. Namun repetisio atau pengulangan kata adalah yang penulis rekomendasikan. Orton mengatakan bahwa segala sesuatu yang dapat diungkapkan dengan satu kata penting, gagasan atau kata benda, subjek atau objek, dihitung sebagai satu kesatuan; setiap tindakan, umum atau spesifik, dengan atau tanpa akhiran, kata ganti, kata sifat atau kata keterangan, suatu angka, kata penting apapun dalam kalimat tersebut mewakili satu unit. ${ }^{43}$ Raabe pun memiliki pendapat yang sama, dimana penentuan unit bisa didasarkan pada pengulangan kata atau kata-kata kunci. ${ }^{44}$ Intinya, sebuah unit ditentukan oleh kata kunci atau kata yang sering diulang, entah berupa kata benda, kata kerja, atau kata sifat. Dengan demikian, repetisio bermanfaat bagi pembentukan unit-unit garis besar.

Metode yang penulis pakai dalam menentukan unit-unit adalah dengan mencari repitisio kata-kata serupa yang diulang-ulang. Penyelidikan dimulai dari ayat 3-20 sebab ayat 1-2 dan 21 merupakan inklusio. Keterangan di bawah ini kiranya membantu pembaca memahami proses pembagian unitnya:

${ }^{39}$ E.W. Bullinger, Figure of Speech Used In The Bible (New York: Messrs E. \& J. B. Young \& Co., 1898), 263.

${ }^{40}$ Ibid.

${ }^{41}$ Misalnya saja: 1) Mesarchia, yakni pengulangan kata yang sama di awal dan tengah kalimat; 2) Mesodiplosis, yakni pengulangan kata yang sama di tengah kalimat; 3) Mesoteleuton, yakni pengulangan kata yang sama di tengah dan di akhir kalimat; dsb. Lihat E.W. Bullinger, Figure of Speech Used In The Bible, 169-318.

42 Ibid, 263.

${ }^{43}$ Hans Kosmala, "Form and Structure in Ancuient Hebrew Poetry (A New Approach)," Poetry in the Hebrew Bible: Selected Studies from Vetus Testamentum, peny. David E. Orton, (Leiden: Koninklijke Brill NV, 2000), 4.

${ }^{44}$ Paul R. Raabe, "Psalm Structures: A Study of Psalms with Refrain," JSOT Supplement Series 104 (Sheffield: Sheffield Academy Press, 1990), 27. 
3. Besarlah TUHAN dan sangat terpuji dan kebesaran-Nya tidak terduga.

4. Angkatan demi angkatan akan memegahkan pekerjaanpekerjaan-Mu dan akan memberitakan keperkasaan-Mu.

5. Semarak kemuliaan-Mu yang agung dan perbuatanperbuatan-Mu yang ajaib akan kunyanyikan.

6. Kekuatan perbuatan-perbuatan-Mu yang dahsyat akan diumumkan mereka, dan kebesaran-Mu hendak kuceritakan.

7. Peringatan kepada besarnya kebajikan-Mu akan dimasyhurkan mereka, dan tentang keadilan-Mu mereka akan bersorak-sorai.

8. TUHAN itu pengasih dan penyayang, panjang sabar dan besar kasih setia-Nya.

9. TUHAN itu baik kepada semua orang, dan penuh rahmat terhadap segala yang dijadikan-Nya.

10. Segala yang Kaujadikan itu akan bersyukur kepada-Mu, ya TUHAN, dan orang-orang yang Kaukasihi akan memuji Engkau.

11. Mereka akan mengumumkan kemuliaan kerajaan-Mu, dan akan membicarakan keperkasaan-Mu,

12. untuk memberitahukan keperkasaan-Mu kepada anak-anak manusia, dan kemuliaan semarak kerajaan-Mu.

13. Kerajaan-Mu ialah kerajaan segala abad, dan pemerintahan-Mu tetap melalui segala keturunan. TUHAN setia dalam segala perkataan-Nya dan penuh kasih setia dalam segala perbuatan-Nya.

14. TUHAN itu penopang bagi semua orang yang jatuh dan penegak bagi semua orang yang tertunduk.

15. Mata sekalian orang menantikan Engkau, dan Engkau pun memberi mereka makanan pada waktunya;

16. Engkau yang membuka tangan-Mu dan yang berkenan mengenyangkan segala yang hidup.

17. TUHAN itu adil dalam segala jalan-Nya dan penuh kasih setia dalam segala perbuatan-Nya.

18. TUHAN dekat pada setiap orang yang berseru kepadaNya, pada setiap orang yang berseru kepada-Nya dalam kesetiaan.

19. Ia melakukan kehendak orang-orang yang takut akan Dia, mendengarkan teriak mereka minta tolong dan menyelamatkan mereka.

20. TUHAN menjaga semua orang yang mengasihi-Nya, tetapi semua orang fasik akan dibinasakan-Nya.

Kebesaran TUHAN

dalam Sifat-Nya

Kerajaan TUHAN

Pemeliharaan TUHAN

bagi Umat-Nya

Seperti dilihat di atas, pengelompokan repetisio atau kata-kata kunci dalam mazmur tersebut menghasilkan empat unit yang membangun garis besar Mazmur 145. Perlu ketelitian yang sedemikian rupa untuk menemukan repetisio yang mampu membentuk unit. Kata-kata yang dicetak miring pada setiap unit menggiring pada sebuah gagasan. Setiap unit mengandung gagasannya masing-masing dan di bawah ini akan dijelaskan mengenai hal tersebut secara lebih rinci. 


\section{Unit I: Kebesaran TUHAN dalam Perbuatan-Nya (ay. 3-6)}

Gagasan dalam unit I ialah "Kebesaran TUHAN dalam Perbuatan-Nya." Kata (gadol) ${ }^{45}$ dan variannya muncul tiga kali dalam ayat 3-6 yang memberi bukti bahwa pemazmur tengah membicarakan kebesaran TUHAN. Secara khusus ialah kebesaran dalam perbuatan TUHAN. Beberapa kosa kata di dalam ayat 3-6 menjelaskan fakta tersebut, dimana perbuatan atau pekerjaan TUHAN lah yang ditonjolkan. Pertama, kata (ma'ase) yang berbentuk jamak dalam ayat 4, yang

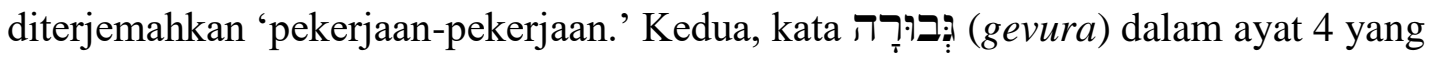
diterjemahkan 'keperkasaan.' Dalam Alkitab NKJV diterjemahkan 'mighty acts' (tindakan-tindakan akbar). Terjemahan NKJV lebih tepat, sebab kata gevura dapat diartikan dengan 'perbuatan-perbuatan akbar TUHAN.' ${ }^{46}$ Ketiga, kata dalam ayat 5 yang memang secara umum berarti 'perkataan', namun Brown dan kawan-kawan menunjukkan bahwa kata ini bisa berarti 'tindakan' jika merupakan kata benda construct. ${ }^{47}$ Kata davar dalam ayat 5 ini merupakan kata benda conctruct .

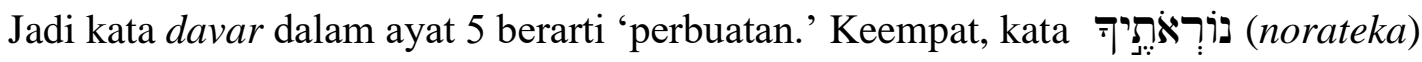
dalam ayat 6 yang oleh LAI diterjemahkan 'perbuatan-perbuatan.' Senada dengan LAI, NKJV menerjemahkannya dengan 'acts.' Sebetulnya arti dasar kata ini adalah 'takut' (dari kata dasar רִירָ atau yare), namun makna yang disarankan untuk ayat 6 ini adalah 'perbuatan-perbuatan Allah yang menggentarkan. ${ }^{48}$

\section{Unit II: Kebesaran TUHAN dalam Sifat-Nya (ay. 7-9)}

Gagasan dalam unit II ialah "Kebesaran TUHAN dalam Sifat-Nya." Dalam ayat 7-9 kata 'besar' muncul dua kali tetapi masing-masing menggunakan kata Ibrani yang berbeda. Pemazmur memakai kata רב ( $\mathrm{rav}$ ) pada ayat 7. Kata tersebut memang memiliki arti 'besar,' namun sifatnya kuantitatif atau bisa dihitung. ${ }^{49}$ Pemakaian kata ini dalam konteks menjelaskan kebajikan TUHAN (ט)). Barangkali pemazmur sedang menghitung-hitung wujud kebaikan TUHAN di dalam hidupnya. Kata kedua yang dipakai adalah לị (gadol) di ayat 8. Berbeda dengan rav, gadol sifatnya kualitatif. Lagi-lagi kebesaran TUHAN lah yang dipuisikan oleh pemazmur. Hanya saja kali ini sifat-sifat TUHAN lah yang menjadi materi pokok dalam unit ini.

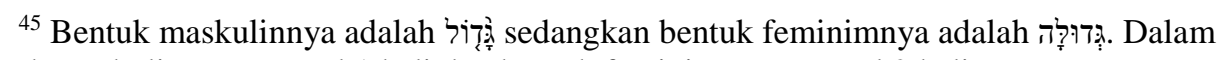
ayat 3-6 bentuk maskulinnya muncul 1 kali dan bentuk feminimnya muncul 2 kali.

${ }^{46}$ Francis Brown, S.R. Driver, Charles A. Briggs, The Brown-Driver-Briggs Hebrew and English Lexicon, 150.

${ }^{47}$ Ibid, 182. Kata benda construct (bentuk terikat) biasa dijumpai pada kasus genitif; biasanya ada dua kata berbeda yang menjadi satu kesatuan.

${ }^{48}$ Leonard J. Coppes, TWOT (3509) dalam Bibleworks 9.

${ }^{49}$ Francis Brown, S.R. Driver, Charles A. Briggs, The Brown-Driver-Briggs Hebrew and English Lexicon, 912. Kata (rav) bisa juga diterjemahkan 'many' dan 'quantities'. 


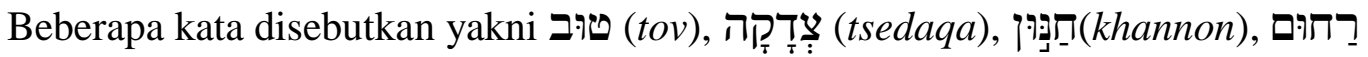

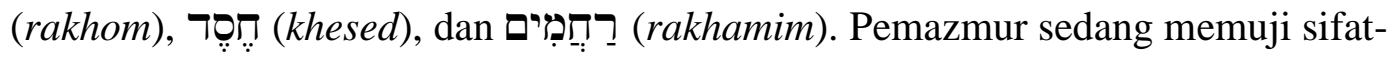
sifat TUHAN. TUHAN itu baik, adil (atau benar), penyayang (atau ramah), panjang sabar (atau penuh kepedulian), setia, dan berbelas kasihan. Sifat-sifat tersebut dapat dinikmati semua orang bahkan semua ciptaan. Di ayat 9 pemazmur menggunakan

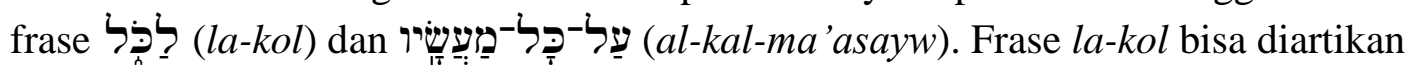
'everyone' atau 'semua orang. ${ }^{50}$ Sementara frase al-kal-ma'asayw dapat diartikan 'product' atau 'created things' (produk atau benda ciptaan). ${ }^{51}$ Pemazmur memuji karena sifat-sifat TUHAN dapat dinikmati segala makhluk ciptaaan-Nya.

\section{Unit III: Kerajaan TUHAN (ay. 10-13)}

Kerajaan TUHAN merupakan gagasan yang diangkat dalam unit III.

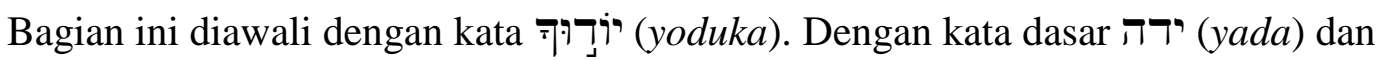
dengan bentuk orang ketiga plural, yoduka menjelaskan bahwa semua ciptaan (ay. 9) hendak memuhi TUHAN. Yang dipuji ialah Kerajaan-Nya. Hal ini dibuktikan dengan

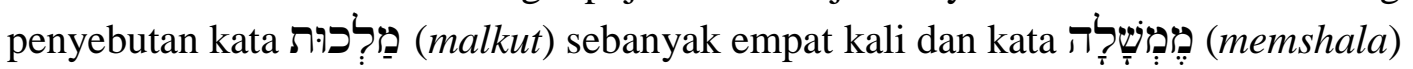
sebanyak satu kali. Masing-masing diterjemahkan 'kerajaan' dan 'pemerintahan.' Hasel menyebutkan bahwa 'kerajaan Allah' merupakan salah satu tema di dalam Perjanjian Lama. ${ }^{52}$ Kerajaan tersebut merupakan realitas masa kini yang menekankan pemerintahan universal Allah di tengah keadaan yang sepertinya menyangkalnya dan di sisi lain kerajaan yang dimaksud berkaitan dengan pengharapan messianik. ${ }^{53} \mathrm{Jadi}$, pemerintahan TUHAN telah dipahami bersifat universal, tak sekedar regional saja.

\section{Unit IV: Pemeliharaan TUHAN bagi Umat-Nya (ay. 14-20)}

Gagasan mengenai 'Pemeliharaan TUHAN bagi Umat-Nya' pada unit IV dapat dilihat dari penggunaan kata 'TUHAN' dan 'orang' dalam ay. 14-20 menurut

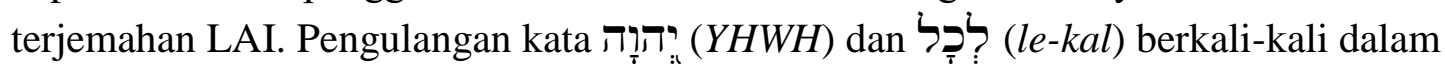
bagian tersebut menunjukkan adanya relasi personal TUHAN dengan umat-Nya. Diperlihatkan bahwa TUHAN mencukupkan kebutuhan umat-Nya (ay. 15-16) dan menjadi Penolong sekaligus Pembela bagi umat-Nya yang bergumul (ay. 14, 17-20). Goulder berkata bahwa pemeliharaan TUHAN yang terkait penyediaan makanan, membuat Mazmur 145 menjadi favorit untuk digunakan dalam menyambut dan mensyukuri makanan; mulanya orang Yahudi menggunakannya untuk menyambut makan malam dan gereja mula-mula memakainya untuk menyambut makan siang. ${ }^{54}$

\footnotetext{
${ }^{50}$ Leonard J. Coppes, TWOT (3766) dalam Bibleworks 9.

${ }^{51}$ Francis Brown dkk, The Brown-Driver-Briggs Hebrew and English Lexicon, 795.

${ }^{52}$ Gerhard F. Hasel, Teologi Perjanjian Lama (Malang: Gandum Mas, 2006), 141.

${ }^{53}$ James H. Waltner, Believers Church Bible Commentary: Psalm, 21.

${ }^{54}$ Michael Goulder, “The Psalm of the Return (Book V, 107-150),” 283.
} 
Kiasan adalah cara berbahasa yang umum dipakai di dalam sebuah puisi. Karya E.W. Bullinger berjudul Figure of Speech Used in the Bible sangat direkomendasikan untuk memahami berbagai jenis kiasan. Beberapa kiasan dipakai dalam Mazmur 145 untuk mengekspresikan gagasan pokoknya.

\section{Hendiadis}

Hendiadis adalah penggunaan dua kata berbeda untuk menegaskan satu gagasan yang sama. ${ }^{55}$ Dua kata tersebut dihubungkan dengan konjungsi 'dan'. Hendiadis dapat ditemukan dalam inklusio melalui kata 'seterusnya' dan 'selamanya'. Dalam teks Ibrani, kata עִ עִ עַר (od) merupakan noun (kata benda) dengan makna 'kekekalan'. Namun ketika pemazmur secara ekspresif mengutarakan: "Aku hendak memuji nama-Mu untuk seterusnya dan selamanya," hal ini jelas berarti pemazmur ingin senantiasa memuji TUHAN sepanjang umur hidupnya. Gagasan di balik hendiadis 'seterusnya dan selamanya' ialah panjangnya usia sang pemazmur.

\section{Sinekdoke}

Sinekdoke merupakan pertukaran dari satu ide kepada ide lain yang berkaitan. ${ }^{56}$ Dua kata berbeda digunakan, namun keduanya masih memiliki hubungan generik. Umumnya, kiasan ini menunjukkan keseluruhan melalui bagian atau bagian melalui keseluruhan. ${ }^{57}$ Ada beberapa jenis sinokdoke yang dikenali, di antaranya Sinekdoke Pars Pro Toto, Sinedoke Totem Pro Parte, Sinekdoke Genus, dan Sinekdoke Spesies.

Sinekdoke dapat ditemukan di dalam ayat 21, pada kata 'mulutku'. Jenis sinokdoke yang dipakai ialah Pars Pro Toto (sebagian untuk keseluruhan). Satu bagian tubuh dipakai untuk menjelaskan keseluruhan manusia (wholeness of man). Ketika pemazmur berkata: "Mulutku mengucapkan puji-pujian kepada TUHAN," maka seluruh hati dan jiwa juga turut dilibatkan. Jelas pujian yang tulus hanya tak

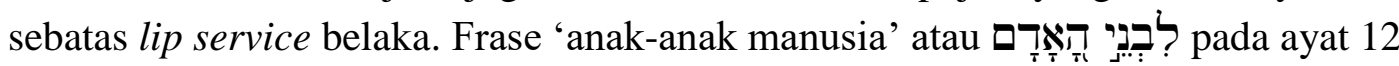
juga merupakan Sinekdok Pars Pro Toto, sebab yang dimaksud tentunya ialah 'manusia,' bukan 'anak manusia' sebagai hasil reproduksi secara biologis.

Jenis sinekdoke yang lain dijumpai pada frase 'segala makhluk' dalam ayat 21 (inklusio). Jenis sinekdoke yang dipakai adalah sinekdoke genus. Isitlah ini menjelaskan tentang 'orang-orang'; makhluk merupakan genusnya, manusia merupakan spesiesnya. Jadi, ketika pemazmur mengatakan: "Biarlah segala makhluk memuji nama-Nya," maka yang sedang dimaksud ialah "Biarlah orang-orang memuji nama-Nya.” Pemazmur menghimbau orang-orang untuk memuji TUHAN.

\footnotetext{
${ }^{55}$ E.W. Bullinger, Figure of Speech Used In The Bible, 657.

${ }^{56}$ Ibid, 613.

${ }^{57}$ Carl A. Reed, Diktat Kuliah: "Puisi dalam Kitab PL," 19.
} 


\section{Metonomia}

Metonomia cara menyebutkan sesuatu secara tidak langsung, yaitu dengan menyebutkan benda atau sesuatu yang lain yang erat hubungannya dengan yang dimaksudkan itu. ${ }^{58}$ Metonomia dapat dijumpai pada ayat 13, dalam klausa “Pemerintahan-Mu tetap melalui segala keturunan." Frase 'segala keturunan' atau (סָרוֹר וָדוֹר (dor wador) adalah yang dimaksud. Frase tersebut pada dasarnya sedang menjelaskan gagasan 'kekekalan' pemerintahan TUHAN. Bagian ini paralel dengan kola sebelumnya di ayat yang sama, yakni dalam frase "kerajaan segala abad." Intinya, Daud sedang memuji sifat kerajaan TUHAN yang kekal.

\section{Metafora}

Secara singkat, metafora bisa didefinisikan sebagai "analogi kualitatif." 59 Aspek yang sama menjadi titik berat kiasan ini tatkala membandingkan dua hal yang sifatnya berbeda. Metafora dapat dilihat pada ayat 14: "TUHAN itu penopang bagi semua orang yang jatuh dan penegak bagi semua orang yang tertunduk," pada frase 'orang yang jatuh' dan 'orang yang tertunduk.' Yang dimaksud bukanlah orang yang tubuhnya terjatuh ke tanah atau orang yang kepalanya menunduk melihat ke bawah. Gagasan di dalamnya ialah "keterpurukan." Pemazmur sedang memuji TUHAN yang bersedia memulihkan orang yang sedang dalam keterpurukan.

\section{Antropomorfisme}

Sebuah gaya bahasa yang menggambarkan Allah memiliki atribut fisik seperti manusia, itulah arti antropomorfisme. Perbandingan macam ini bukan supaya orang merasa bahwa Allah memiliki bentuk atau sifat manusia, melainkan untuk mengomunikasi sesuatu tentang pribadi Allah. ${ }^{60}$ Sebuah klausa di dalam ayat 16 mengatakan: "Engkau yang membuka tangan-Mu." Pemazmur menggambarkan TUHAN memiliki organ tangan seperti manusia, yang mampu digenggam dan dibuka. Namun yang ditekankan di sini bukanlah morfologi TUHAN, sebab Alkitab mengajarkan bahwa Ia adalah Roh. Klausa tersebut merupakan ekspresi pemazmur tentang kebaikan TUHAN yang menjadi penyedia dan penolong bagi umat-Nya yang membutuhkan.

\section{Konstruksi dan Tema Mazmur 145}

Setelah membahas mengenai perangkat retorika dalam Mazmur 145, baik struktur maupun tekstur yang memberi petunjuk tentang tema, maka berdasarkan itu semua penulis mengonstruksikan Mazmur 145. Sebelumnya perlu diketahui bahwa struktur yang umum untuk mazmur bergenre Mazmur Pujian adalah sebagai berikut:

\footnotetext{
${ }^{58}$ Dendy Sugono, Kamus Bahasa Indonesia, 952.

${ }^{59}$ Gorys Keraf, Diksi dan Gaya Bahasa (Jakarta: Gramedia, 2004), 137.

${ }^{60}$ Carl A. Reed, Diktat Kuliah: "Puisi dalam Kitab PL," 12.
} 
I) Ajakan untuk Memuji Tuhan; II) Alasan untuk Memuji Tuhan; III) Ajakan Baru untuk Memuji Tuhan. ${ }^{61}$ Dari strukur yang umum dipakai tersebut, diperolehlah konstruksi Mazmur 145 yang penulis usulkan sebagai berikut:

\section{Mazmur 145}

(Tema: Memuji TUHAN Seterusnya \& Selamanya)

A. Inklusio: Memuji TUHAN Seterusnya dan Selamanya (ay. 1-2)

(Deklarasi personal menyembah TUHAN)

B. Alasan Untuk Memuji TUHAN (ay. 3-20)

I. Karena Kebesaran TUHAN dalam Perbuatan-Nya (ay. 3-6)

II. Karena Kebesaran TUHAN dalam Sifat-Nya (ay. 7-9)

III. Karena Kerajaan TUHAN (ay. 10-13)

IV. Karena Pemeliharan TUHAN atas Umat-Nya (ay. 14-20)

C. Inklusio: Memuji TUHAN Seterusnya dan Selamanya (ay. 21) (Persuasi komunal menyembah TUHAN)

Jadi, temanya ialah "Memuji TUHAN Seterusnya \& Selamanya," dan di dalam garis besarnya tercantum alasan-alasan mengapa umat TUHAN memuji Dia seumur hidup mereka.

\section{Konklusi}

Guna menemukan gagasan utama dalam sebuah mazmur, maka seseorang harus terlebih dahulu menemukan dan memahami perangkat retorika apa saja yang terkandung di dalamnya. Setiap perangkat retorika yang dipakai bukan saja memiliki tujuan estetis oleh penggunanya, namun juga menggiring pembaca menemukan tema. Di dalam Mazmur 145 dapat ditemukan beberapa perangkat retorika seperti inklusio, akrostik, repetisio, dan beberapa kiasan seperti hendiadis, sinekdoke, metonomia, metafora, dan antropomorfisme. Varian perangkat retorika tersebut menuju pada satu muara, yakni tema mazmur itu sendiri. Lewat penyelidikan dan pemahaman yang saksama, ditemukanlah tema dan garis besar sebagaimana yang telah dijelaskan.

${ }^{61}$ Tremper Longman III, Bagaimana Menganalisa Kitab Mazmur, 20. 


\section{Bibliografi}

Bartholomew, Craig G. Reading Proverbs with Integrity. Cambridge: Grove Books, 2001.

Brown, Francis, S.R. Driver, Charles A. Briggs. The Brown-Driver-Briggs Hebrew and English Lexicon. Oxford: Clarendon Press, 1907.

Brugg, John F. "Biblical Acrostics And Their Relationship To Other Ancient Near Eastern Acrostic," NEH Seminar: The Bible And Near Eastern Literature (1997).

Bullinger, E.W. Figure of Speech Used In The Bible. New York: Messrs E. \& J. B. Young \& Co., 1898.

Bullock, C. Hassel. Kitab-kitab Puisi dalam Perjanjian Lama. Disunting oleh Sumarah. Diterjemahkan oleh Suhadi Yeremia. Malang: Gandum Mas, 2014.

Carley, Keith. "Psalm 8: An Apology for Domination" Reading from the Perspective of Earth. Disunting oleh Norman C. Habel. Sheffield: Sheffield Academic Press, 2000.

Coppes, Leonard J. Theological Wordbook of the Old Testament. Disunting oleh R. Laird Harris. Chicago: Moody Press, 1981.

Cowley, A.E. Gesenius Hebrew Grammar. New York: Oxford University Press, 1910.

Foster, Benjamin R. "Literature and Poetry, Ancient Near East" dalam The Encyclopedia of Ancient History. Disunting Roger S. Bagnall dkk. Edisi Pertama. Hoboken, New Jersery: Blackwell Publiher, 2013.

Goulder, Michael D. The Psalms of the Return: Book V, Psalm 107-150. Disunting oleh David J.A. Clines dan Philip R. Davies. Sheffield: Sheffield Academic Press, 1998.

Goulder, Michael. "The Psalm of the Return (Book V, 107-150)," Journal for the Study of the Old Testament (1997).

Grossberg, Daniel. "The Disparate Elements Of The Inclusio In Psalms," HAR 6 (1982).

Hasel, Gerhard F. Teologi Perjanjian Lama. Malang: Gandum Mas, 2006.

Keraf, Gorys. Diksi dan Gaya Bahasa. Jakarta: Gramedia, 2004.

Kosmala, Hans. "Form and Structure in Ancuient Hebrew Poetry (A New Approach)," Poetry in the Hebrew Bible: Selected Studies from Vetus Testamentum. Disunting oleh David E. Orton. Leiden: Koninklijke Brill NV, 2000.

Longman III, Tremper. Bagaimana Menganalisa Kitab Mazmur. Diterjemahkan oleh Cornelius Kuswanto. Malang: Literatur SAAT, 2012).

Nurgiyantoro, Burhan. Teori Pengkajian Fiksi. Yogyakarta: Gadjah Mada University Press, 1995.

Pradopo, Rachmat Djoko. Pengkajian Puisi. Yogyakarta: Gadjah Mada university Press, 2000. 
Raabe, Paul R. "Psalm Structures: A Study of Psalms with Refrain," JSOT Supplement Series 104. Sheffield: Sheffield Academy Press, 1990.

Reed, Carl A. Diktat Kuliah: "Puisi dalam Kitab PL." Yogyakarta: STTII, t.t.

Snearly, Michale K. The Return of The King: Messianic Expectation in Book Vof the Psalter. New York: Bloomsbury Publishing, 2016.

Spuy, Roelie van der. "Hebrew Alphabetic Acrostic - Significance and Translate," OTE 21/2 (2008).

Stek, John H. "The Stylistics of Hebrew Poetry," Calvin Theological Journal 9.1: 1530. Grand Rapids, Michigan: Calvin Theological Seminary, 1974.

Sugono, Dendy. Kamus Bahasa Indonesia. Jakarta: Pusat Bahasa, 2008.

Waltner, James H. Believers Church Bible Commentary: Psalm. Diterjemahkan oleh Elmer A. Martens dan Willard M. Swartley. Pennsylvania: Herald Press, 2006.

Whybray, Norman ."Reading The Psalms As A Book," Journal for the Study of the Old Testament. Sheffield: Sheffield Academic Press, 1996.

Wicaksono, Andri. Pradopo dalam Catatan Ringkas Stilistika. Yogyakarta: Garudhawaca, 2014. 